\title{
A constructionist defence of environmental ethics: the case of the Swiss hunter
}

\author{
T. Tait-Jamieson \\ Department of Geosciences, University of Fribourg, Fribourg, Switzerland \\ Correspondence to: T. Tait-Jamieson (timothy.tait-jamieson@unifr.ch)
}

Received: 7 March 2014 - Revised: 13 June 2014 - Accepted: 20 June 2014 - Published: 8 October 2014

\begin{abstract}
Castree argues that, due to implicit and explicit forms of material essentialism within many environmental ethicist arguments, a post-environmental ethics may be inevitable. The purpose of this article was to examine this claim by putting authors Castree and Proctor into a dialogue, situated within the social context of hunting in Switzerland, with the aim of navigating a path beyond the ontological mine field that environmental ethics has recently become. The results show that the critique that Castree offers can be turned into a mode of enquiry that highlights the need for environmental ethics to move beyond normative prescription to normative description. Such a move, as highlighted by the case of the Swiss hunter, allows for enquiry into how environmental ethics are socially discussed and produced, as well as offering avenues in which to interrogate and make sense of the different ways that people understand and interact with the natural world.
\end{abstract}

\section{Introduction}

\subsection{Environmental ethics}

In recent times, concerns relating to how people view, use and relate to the natural environment have exploded into the consciousness of many people (Rolston III, 2003). "We have seen ordinary suburban people, the elderly and the retired, young schoolchildren and working-class families out on the street protesting nature issues" (Franklin, 2002, p. 1). The fact that environmental issues have increasingly become a topic of discussion in public, political and academic circles is perhaps of little surprise, particularly when one considers the gravity of the issues being discussed (such as climate change, deforestation, pollution and loss of biodiversity and ecosystems). One major body of academic work that focuses on the normative aspects of these environmental issues, as well as the ways in which societies interact with the natural environment, is the philosophical field of environmental ethics. As described by Pojman (2005), "environmental ethics concerns itself with these global concerns: humanity's relationship to the environment, its understanding of and responsibilities to nature, and its obligations to leave some of nature's resources to posterity" (p. 2). Within contemporary environmental ethics, there are numerous different positions, approaches and perspectives that advocate many different concerns and world-views. Different perspectives include: anthropocentrism, animal rights/liberation, bio/eco-centrism, land ethics, eco-feminism and deep ecology, to name just a few (Rolston III, 2003). These various perspectives deal with concerns as wide-reaching as "pollution, population control, resource use, food production and distribution, energy production and consumption, the preservation of wilderness and of species diversity" (Pojman, 2005, p. 2). Within these very different and wide-reaching topics, there are numerous debates describing what value is, who or what can give value, and who or what might have value (Valentine, 2004)

In the compact article "A post-environmental ethics?", Castree (2003) implicitly predicts the inevitable demise of conventional environmental ethics ${ }^{1}$. He argues that despite the considerable number and variation of perspectives found within the field of environmental ethics, many ethicists are guilty of basing normative claims on flawed ontological assumptions about the nature of nature. As he points out, debates in the field of environmental ethics tend to be debates

\footnotetext{
${ }^{1}$ Here Castree uses the term environmental ethics to refer to any approach that attempts to allocate value or ethical consideration to things or objects that are often called "nature" or "non-humans". Such an understanding is also one that I use throughout this article.
} 
about ontology. This is because, in order to allocate ethical consideration, environmental ethicists are required to name, characterise and distinguish the nature(s) of material objects they wish to speak about. Therefore, the specific "ontological choices" that are made here play a pivotal role in the deciding and describing of what or who should receive ethical consideration. The ontological choices that environmental ethicists make, Castree (2003) argues, are flawed because they are often based on explicit and implicit forms of material essentialism. $^{2}$ As he describes, explicit material essentialism can be seen in perspectives that argue for an extension of ethical consideration to certain non-humans (e.g. see Singer, 1975) or argue the intrinsic value of nature (e.g. see Lee, 1984). This is because these claims are clearly grounded in certain fixed and absolute characteristics and properties of the objects under consideration - e.g. intelligence and/or ability to feel pain in the former or inherent and intrinsic properties in the latter (Castree, 2003; Valentine, 2004). Similarly, he argues that a type of material essentialism is also expressed in weak and strong versions of social constructionism. As he points out, claiming that nature cannot be known in itself, comes with an implication that an "ontological property of nature [is] not to be capable of ethical expression" (Castree, 2003; p. 6). Implicit forms of material essentialism, Castree (2003) further argues, can be identified in more holistic perspectives of environmental ethics. Here, authors as diverse as Callicott (1989), Naess (1989), Harvey (1996), and Lewis (1960) are broadly grouped together in order to highlight that, despite their efforts to break down social-nature dualism by stressing the interconnectness of these worlds, they "must still confront the issue of who precisely the subjects and objects of ethical considerability are" (p. 7).

For Castree (2003), material essentialism is not a particularly valid way to underpin normative prescriptions because, firstly, the ways that humans speak about, analyse and understand nature will always contain social elements (i.e. nature is never just natural) and, secondly, the material objects are also "relationally shifting" (p. 10; Valentine, 2004). Therefore, many of the ontological choices made by environmental ethicists in the construction of their environmental prescriptions and arguments have the consequence of invalidating any moral or ethical claims that they may have. In other words, because the foundations are rotten, the house cannot stand. Such criticism has not been well received, particularly as it is seen to destabilise both claims on truth, and the ability to name objects and processes, which play such an important role in establishing the guiding force required by ethical prescriptions (Proctor, 2001). Does this mean we should follow the advice of Castree and condemn environmental ethics to the proverbial scrap heap? I argue no, well not yet, at any rate.

\footnotetext{
${ }^{2}$ Castree describes material essentialism as "the idea that entities in the world - [...] - ultimately have a set of immutable properties that are relatively or absolutely autonomous from those of other entities and relatively enduring" (p. 3-4).
}

To do this I will take a journey into the physical and moral world of recreational hunting in Switzerland. I will follow Proctor's (2001) advice to find a path beyond this crushing ontological dead end and use the social construction of nature and Castree's analysis to examine the ways that environmental morality and ethics are socially discussed and developed. In this way we can just perhaps hope to enrich and revegetate the field of environmental ethics.

\subsection{Immoral hunting?}

The place of recreational hunting in contemporary Western societies is highly contested (Leader-Williams, 2009; McLeod, 2007). Numerous animal rights and environmental groups oppose hunting, mainly because it often results in the death and suffering of wild animals, and/or this killing is done for seemingly trivial reasons, such as recreation, sport or trophies (Cahoone, 2009; Gunn, 2001). Furthermore, the character of hunters is often brought into question. As Altherr and Reiger (1995) describe, hunters are often perceived as "....sadistic male[s] armed to the teeth with survival and assault weaponry, 'blasting' Bambi or another Disneyified animal with saucer-sized eyes to death" (p. 39). Beyond the characterisation of hunters as sadistic, cruel and violent, others also perceive hunters as inadequate or perhaps subhuman. For example, Williams (1995), writes: "Hunters are piggy...they're overequipped...insatiable, malevolent and vain. They maim and mutilate and despoil. And for the most part they're inept. Grossly inept" (p. 256). Similar perceptions can also be found in popular culture where hunters tend to play villainous and often imbecilic characters in films and television series (Cartmill, 1996). The classic example of this would be Disney's 1942 animated film "Bambi", where the shadowy hunter murders Bambi's mother (Cartmill, 1996). A more current example of such a portrayal of a hunter can be found in the 2006 computer-animated film "Open Season" (Murdocca, 2006), wherein the hapless hunters are portrayed as blood-thirsty, gun-toting idiots, who wish to shoot anything that moves with no concern for the things they shoot. Clearly there is negative stigmatism attached to hunters and the hunting practices, so much so that this activity is widely regarded as having a major image problem (Keel, 1996).

Against this, hunting proponents engage with hunting opponents by justifying hunting in a number of ways. A particularly prevalent justification is the argument that hunting can benefit environmental conservation (Dickson, 2009). As Dickson (2009) points out, hunting can benefit conservation both directly and indirectly: directly through the regulation of certain populations or, indeed, the removal of "exotic" or "introduced" species, and indirectly through the generation of funds (e.g. from hunting permits) that can be used in conservation projects. Such a justification focuses on the cumulative and indirect positive effects that hunting can have on the conservation of the entire natural environment, while overlooking the actual killing of individual animals (Dickson, 
2009; Simpson and Cain, 2001). Realisation of these positive effects is often said to rest on a number of key aspects, such as "correct" scientific knowledge of the workings and processes of local ecologies, the implementation of conservation-based plans and regulations and hunters actually abiding by these plans and regulations (Cahoone, 2009; Dickson, 2009). Beyond the benefit to conservation, hunting is also justified by the opportunity it provides people to have a closer and more realistic relationship with the natural environment (Peterson et al., 2011). For example, instead of purchasing some "de-animalized" piece of meat in a supermarket, hunters go out and kill an animal for their food, often also doing the butchering themselves (Cahoone, 2009). As Knezevic (2009) points out, in many modern societies the connection people make between food and its origin (e.g. the natural environment) is becoming more and more fragile. For some this connection is particularly important because, as Cahoone (2009) put it, "ignorance of food is ignorance of our most basic relation to nature" (p. 83). Hunting is therefore justified because it provides people with the opportunity to have both a more realistic and knowledgeable relationship with their natural surroundings: realistic in the sense that death is a natural part of the natural world, and knowledgeable because hunters tend to know a great deal about the wildlife that lives in their local area, not just about the species they hunt (Cahoone, 2009; Knezevic, 2009).

A strong feature of the society-wide discussions surrounding hunters and hunting practices is the ferocity and intensity with which different actors voice their opinions (Dickson, 2009). Dickson (2009) suggests that, even though the subject of this debate is hunting, on another level what is also being discussed is the relationship between humans and nature (or human-nature relationship). Particularly, what is the relationship that people have with the natural environment and/ or what should this relationship actually look like?

\subsection{Hunting in Switzerland}

Hunting in Switzerland has a long history and is strongly cemented in the country's cultural fabric. It is said that hunting practices in Switzerland can be traced back as far as 200000 years (K. Müller, 2008). In canton Grisons (the focus area of this study), thanks to the revolutionary Articles of Ilanz (1526) all local citizens and communities have held the almost exclusive rights to control and take part in hunting for more than 500 years. In principle the tradition of the Grisons "freie Jagd" continues to this day, although has gone through a number of periodic developments (Canton Grisons, 2014). Key among these developments is the implementation of a number of restrictive regulations on hunting that first occurred throughout Switzerland in 1875. These early hunting regulations focused primarily on boosting the population number of game animals. At this time, game animals such as ibex (Capra ibex) and red deer (Cervus elaphus) were practically extinct from Switzerland, and roe deer
(Capreolus capreolus) and chamois (Rupicapra rupicapra) only survived in small numbers. Bear (Ursus arctos), lynx (Lynx lynx), and wolf (Canis lupus) were not given protection, and they continued to be exterminated (Blankenhorn, 2008).

In recent times, hunting in Switzerland has taken on a new direction, specifically in regards to the federal and cantonal hunting regulation. This direction puts more emphasis on sustaining and protecting natural species than before. For example, currently the federal government provides the minimum level of hunting rules that individual cantons have to adhere to. These rules are based on four major aims: (1) to protect biodiversity, (2) to protect endangered species, (3) to keep damage to forest and agriculture to a reasonable level and (4) to sustain hunting practices. Each canton is expected to implement hunting in its respective regions, which requires them to adapt the minimal requirements to local conditions (Die Bundesversammlung der Schweizischen Eidgenossenschaft, 2014). Different cantons in Switzerland implement these hunting regulations differently. There are three general types used by cantons: (1) a complete ban on hunting, (2) a Revierjagd system and (3) a Patentjagd system. In the Revierjagd system, hunting zones in the canton are divided and leased to groups such as hunting clubs or associations. An individual must become a member of a group in order to be able to hunt. No quota target is specified; rather the amount of animals taken in a year is reported, which directly affects the cost of the lease. In the Patentjagd system (implemented in canton Grisons), the hunting zones are managed directly by the canton. Hunters purchase a permit from the canton for the right to hunt throughout the cantonal region. The number of animals per season that can be hunted in the Patentjagd system is often regulated by a quota system (Bundesamt für Umwelt, 2010). In canton Grisons a quota system is calculated by undertaking an extensive annual biodiversity survey. Within this, systematic observations are undertaken to gain an estimation of the total number of animals living in the region. Factors such as numbers of dead animals found, current illnesses, climatic conditions, the observations of game wardens and the prognoses of past years are taken into consideration in order to develop an annual hunting strategy and establish the amount of necessary regulation to be undertaken in that year's hunt (Amt für Jagd und Fischerei Graubünden, 2013).

Despite its long and colourful history, hunting in contemporary Switzerland is a relatively minor activity. In 2011, some 30412 people in Switzerland bought a permit and presumably went hunting. In the last decade the number of hunters in Switzerland has been very constant, hovering around 30000 per year (Bundesamt für Umwelt, 2013). In spite of the relatively small population, Swiss hunters appear to be rather industrious in terms of the numbers of animals that are killed through hunting practices. In 2012, hunters in Switzerland killed more than 74000 ungulates (e.g. roe deer, chamois, red deer and wild pig (Sus scrofa)); over 36000 
carnivores (red fox (Vulpes vulpes), badger (Meles meles) and beech marten (Martes foina); as well as a relatively large number of other animals (e.g. marmot (Marmota marmot), hare (Lepus europaeus/Lepus timidus), an assortment of water and other bird types) (Bundesamt für Umwelt, 2013).

\section{Methodology}

Marvin (2010) describes hunting as a complex cultural activity. This is because the practice of hunting and the relationships that a hunter has with other hunters, with the animals they seek and the landscape in which this relationship occurs are steeped in social meaning. Because of this cultural complexity as well as the exploratory purpose of this study, a qualitative research approach was chosen. Qualitative research has been described as being useful in exploring and unravelling the complex and often contradictory aspects of human beings (Clifford et al., 2010).

The primary source of data for this study was semistructured interviews and observations. A relatively small number of participants were selected from a region within the canton of Grisons using a snowball sample. Atkinson and Flint (2004) define snowball sampling as a technique that uses an initial contact to provide names of other relevant contacts. These contacts can then offer new names "for an expanding web of contact and enquiry" (p. 1043). A snowball sample was considered an ideal sample method for this project for two reasons. Firstly, a snowball sample was considered useful to overcome concerns regarding access to participants (Atkinson and Flint, 2004). This concern was based on the perceived difficulties that a researcher (of foreign nationality) would have in locating and accessing participants within the tight-knit rural communities, where hunters tend to be strongly protective of the locations that they hunt, their local knowledge and their practices. Secondly, a snowball sample allowed for analysis of the social dynamics and networks that exist in the local hunting community, with the expectation that this would lead to a deeper understanding of social, cultural and moral meanings attached to this activity. The observations, particularly while out hunting, were invaluable to this aim as they allowed for informal introductions and the building of relationships with new individuals (as these hunters often hunt in group), as well as other individuals and groups hunting in the same area. With the help of an initial contact (familiar with many of the inhabitants of the focal area), the researcher was introduced to possible participants, who were then asked to take part in the interviews and observations. The individuals of interest for this study were any person who takes part in hunting activities relatively regularly. Distinctions such as age, sex or hunting experience were not considered.

It was decided that interviews and observations should be conducted in a place of the participant's choice. This decision was based on the aim of creating a comfortable setting in which to explore a number of complex themes. The settings included local pubs and restaurants, the participants' offices and places of business and while out hunting. The primary data gathered through the semi-structured interviews and observations were coded by using standard qualitative content analysis coding procedure (Flick, 2009). The coding process consisted of identifying and grouping different themes contained within segments, passages, sentences and words. Major arising themes included hunting motivation and personal importance, hunter-nature relationships, nature concepts as well as ethical and moral justifications, rationales and considerations. Mind maps were then used as a visual tool in which to unravel the different themes, identify subthemes and explore the types of connections that these themes and subthemes presented. Secondary data were used to gather background information on hunting practices and on the types of debates that surround this practice within Switzerland. Secondary data were collected from local newspapers, NGOs (such as Pro Natura), online news broadcasters (such as Schweizer Fernsehen) and hunting association websites (such as JagdSchweiz). These methods proved to be useful in collecting a large quantity of rich and diverse data that allowed in-depth enquiry and analysis into the complicated world of hunting and human-nature relationships, and to gain a much better understanding of how the participants make sense of the world.

\section{Results}

\section{1 "Recreational" environmental management}

Overall, despite considerable differences in age, levels of hunting experience and occupations, the hunters that participated in this study had surprisingly similar attitudes and opinions about hunting, about the natural environment and about their relationships both to the animals they shoot and to the natural world. First and foremost, hunting is described by the participants of this study as primarily a "hobby"; it is something they enjoy doing, and indeed wish they could do more often. The things that the participants particularly enjoyed about hunting could be split into a number of different but often connected themes. For example, they said that hunting allowed them to spend quality time with their friends and family. This included the time actually spent hunting but also the time that they spent together talking and strategising about hunting as well as preparing and eating the hunted meat. It was clear that hunting formed an important part of social life for the participants. The hunters also enjoyed the mental and physical challenges that they associated with hunting. As a number of the participants pointed out, the larger the challenge, the harder they had to work for it; the more pleasure and satisfaction they got from being successful. Most of all, however, the participants of this study enjoyed hunting because it allowed them to spend a considerable amount of time outside with nature. When 
speaking about this time they spend with nature, the participants invoked ideas of freedom and escape that they felt when they are out hunting. It seemed that through hunting the participants were able to escape from civilisation and the rigours of everyday life. It is worth noting that hunting was not the only outdoors activity that these hunters take part in; many also enjoyed hiking, nature watching and ski touring to name just a few.

Distinct by its absence is the theme of killing in this description of hunting. Other authors - such as Marvin (2010), McLeod (2007) and Leader-Williams (2009) - have also highlighted such an absence in hunter dialogue. As an explanation, Marvin (2010) puts forward the view that the process of hunting (e.g. the strategising, stalking and interacting with friends and family) is of equal if not of more importance than a successful result. He compares this process and its importance in hunting to similar processes in other activities such as mountain climbing. For mountain climbers, if the only aim were to get to the top of mountain, other means (such as helicopter or easier paths) would be acceptable to achieve the goal. However, in mountain climbing as well as hunting achieving the goal (getting to the top of the mountain or the kill) is not the only thing linked to satisfaction. Getting there (in mountain climbing) or stalking/finding prey (in hunting) is often just as important (Marvin, 2010). As famously put by Ortega y Gasset (1996), "one does not hunt in order to kill, but rather the reverse, one kills in order to have hunted (p. 110-111)". Such a view seems to show significant similarities to the description of hunting outlined above by the participants involved in this study.

Interestingly, all the participants wished also to point out that, despite the recreational aspect of hunting, they all felt that they were doing an important environmental job. In their eyes, they were acting as environmental managers regulating the population numbers of certain animal species. By hunting they were in fact conserving the integrity of the overall ecosystem from disturbances related to overpopulation. As one hunter described - because there are no, or at least very few, large predators in Switzerland to regulate the wild populations of large ungulates - people are now required to fill this role. As it turns out, hunters are more than willing to step up and get this job done. Such statements could be seen as a type of justification, justifying hunting based on the service that it provides to the overall health of the natural environment. Statements such as the above one were, at least in part, backed up by the hunters' attitudes towards the returning wolf. Most were excited at the prospect of the wolves and other large predators returning to the Swiss Alps. For example, one hunter described that such a return would signify a return to "real nature" for the region. This is despite the understanding that such a return would likely have an impact on the numbers of animals that could be hunted. Only one hunter described displeasure about the wolf returning. However, this perspective was also strongly connected to the impact the wolf would have on the agricultural prac- tices of the region. While the majority of these hunters appear to accept the return of the wolf, it is hard to gauge if this opinion is widely held by hunters throughout Switzerland. As Wallner and Hunziker (2001) highlight, hunters' opinion about the wolf varies substantially and ranges from strong opposition to complete acceptance. For example, as shown by Imoberdorf (2012), hunters in canton Valais appear to be strongly against this possible return. Alternatively, JagdSchwiez's (Switzerland's nationwide hunting association) position can be seen as somewhere in the middle of this range. In a number of opinion pieces, JagdSchweiz has outlined their position towards the wolf and other large predators (such as the lynx and brown bear). They have been somewhat careful not to comment on the question of whether they (wolf, lynx and bear) should come back to Switzerland, instead focusing on what they see as a need for stronger regulation powers. This means that, should these animals (currently protected by conservation laws) return in significant numbers, they too should be managed in a similar way to large ungulates (T. Müller, 2008). An interpretation of this response would be that many hunters are likely to be acutely aware of the contradiction that nonacceptance reveals and thus position themselves in such a way to limit negative criticism upon their already controversial practice. It would seem that, although not (openly) opposed to the wolf, they are not exactly happy with its possible return and feel that they are likely to be adversely effected.

\section{2 "Loving-killing" paradox}

When one reflects on the hunting experience as described by the hunters themselves, one can see a considerable amount of intensity and intimacy in the hunters' relationships with the animals they shoot and the location in which this interaction takes place. As Marvin (2010) points out, the interaction and relationship that hunters have with the natural environment is unique in contemporary societies. Such an interaction is on a completely different level to other so-called outdoor activities such as mountain biking, hiking and ski touring. For example, imagine you are alone in a forest intently preparing for an animals to appear, and then you see it, you identify it, you shoot it, you watch it die, you drink the "palorma" (a salute in the form of a sip of strong alcohol from a hip flask), you carry it home and then you prepare it to eat it. Indeed, the hunter's interaction with nature can be seen as specific and particular to this activity (Marvin, 2005). As Cavalhedo Reis (2009) explains, "these engagements involve an embodied encounter with nonhuman animals that is rich in meanings and sensualities in ways that few other recreational activities are able to provide" (p. 574). So it was of little surprise that the participants in this study felt that they have a very close relationship with nature. What is interesting about this close relationship is that, for the hunters involved in this study, it also includes ideas of care and loving. For example, many of the attitudes and opinions of these hunters seemed rather 
environmental. In fact a number went so far as to describe themselves as "nature lovers".

Despite this feeling of care and connectedness, for 21 days in September, these nature lovers go out and do their best to kill certain parts of this nature. This seems rather contradictory: how is it that these hunters talk about themselves as lovers of nature on the one hand, but on the other hand actively destroy a part of the very nature they love? Killing is almost always perceived as a violent and destructive action and is rarely associated with ideas of love and caring. Such a contradiction was also discovered by McLeod (2007), in an exploration of duck hunters in New Zealand. As she writes, "what is perhaps confusing about duck hunters' relationship with nature (at least from a non-hunter's perspective) is that they both love nature but also want to kill aspects of it" (p. 164). A couple of questions arise from such observations, namely, are hunters aware of this contradiction, and can this contradiction be philosophically resolved?

\subsection{Resolving the "loving-killing" paradox?}

We can try to resolve this apparent contradiction by closely viewing the hunter-nature relationship. McLeod (2007) points out that some hunters believe that they have a realistic view of nature, one that sees death as just a part of nature. This is a practical resolution that overcomes the loving and killing contradiction by viewing death (in this context at least) as neither bad nor good: it just is. However, observing how hunters treat death, this resolution is unlikely to be the whole story. Many of the participants described the importance of respect towards the animals that they kill. A number describe performing rituals of respect such as drinking a palorma, placing tree bows in the mouth of a dead deer and personally carrying the animal carcass home. By showing respect to the animals that they kill, the hunters are showing a level of concern that falls outside of such a cold assessment of life and death. Furthermore, a number of the hunters described the enjoyment that they received from observing animals throughout the year. Living in an area where such animals are hunted and being hunters themselves, they know that is it reasonably likely that they or someone else may kill the animal that they have observed and maybe even admired at other times. This topic was also discussed in the "Einstein: Auf der Jagd" (Schweizer Fernsehen, 2008) television programme:

INTERVIEWER: Hat man als Jäger eigentlich die Tiere gern? (Does one as a hunter like animals?)

HunTeR: Ja gern, das ist noch schwierig. Man schätzt sie. Ich denke schon, irgendwie kann man so ein Wildtier auch gern bekommen, also jetzt in meinem Fall, wenn ich immer ins Asyl hinüber schaue, und immer die gleichen Hirsche sehe, muss ich jetzt ganz ehrlich sein, bin ich eigentlich fast froh, wenn sie die Jagd überleben. Sie müssen nicht unbedingt geschossen werden. (Well, yes, but it is hard to say. One values them. I do think that somehow you can get to like a wild animal like that. Now in my case, when I look over to the asylum (nature reserve) and always see the same deer, if I am really honest, I am almost glad if they survive the hunt. They do not necessarily have to be shot.)

Clearly then, hunters may see death as a natural part of nature, but this does not mean that they are completely comfortable with it or indeed with the part that they play in such an outcome.

We can also look at the role of these hunters in the management and regulation of wild animal populations. This can clearly be used to justify hunting practices based on the premise that it provides a positive service to the natural environment. This perspective overlooks the life or wellbeing of certain individual animals and plants in favour of protecting the integrity of the entire ecological system. However, there is a considerable discrepancy here, between philosophical or theoretical arguments and actual action. It is one thing to agree that the population of, for example, red deer need to be regulated because overpopulation will result in a devastating effect on the forests and the natural environment as a whole; it is quite another thing to actually go out and do something about it. Quite clearly, in this context, actually doing something requires rolling up one's sleeves and killing animals. This is something that most people that consider themselves as "lovers of nature" are likely to have a problem with.

Marvin (2010) makes an interesting point. He argues that, by hunting, people are participating in nature, and through this participation they are in fact becoming part of nature. Taking into consideration that these hunters feel they are doing the job of absent predators and the perceived importance of this interaction, one can certainly make this connection. However, the mode in which the hunters speak of nature contradicts this conclusion. They may be participating in nature, but they do not consider themselves as part of nature. This is particularly evident when they speak of managing and regulating the population of wild animals. Terms such as regulation and managing do not imply that these hunters are participating in the sense of being an integrated part of a process, but rather of an overseer - both separate and detached. Such a belief is troubling, particularly when we consider the regulatory effect that they have on the natural environment. While hunters may see themselves as being separate from nature, it is quite difficult to separate nature from them.

\section{Discussion}

The moral controversy that surrounds recreational hunting practices and the strength of convictions from different actors has been particularly revealing. It is clear that, for the hunters involved in this study, morality plays a significant role in guiding their interactions and relationships with the natural 
environment. However these are complex and, as highlighted by the loving and killing contradiction, rather paradoxical. These moralities are further complicated by tangled understandings as to their place in regards to, and the nature of, the natural world. A close analysis of these complexities reveals that in Switzerland, where concerns and sensitivities for the natural environment are heightened, the controversy that surrounds hunting practices puts the future of hunting in a particularly precarious position. But hunting is not likely to disappear anytime soon. A key reason for this is that hunting has a long history here, and it has developed and evolved through time. It has moved on from an activity that caused the (almost) extinction of animals such as the wolf and the ibex, to one that is actively focused on sustaining and managing the natural environment (Breitenmoser, 1998). Therefore hunters sit uncomfortably in a situation where they are simultaneously loathed and loved: loathed because of the enjoyment that they receive from killing wild animals, and loved because this killing fulfils an environmental requirement that arguably no one else is prepared to do. Furthermore, as one of the participants involved in this study pointed out, hunting makes economic sense. In canton Geneva, where hunting is forbidden, rangers are employed to regulate the populations of certain animals. In other cantons, hunters pay the authorities for the right to do this job.

Such a development reveals certain characteristics about the ways that Swiss contemporary society generally perceives human-nature relationships. It shows that Swiss people appear to care about the natural environment in quite a holistic way and that they believe that managing the stability of it is the best way to conserve it. Interestingly, if people take this belief seriously, the loving-killing paradox does not just exist for the hunter; it exists for everybody. It is just that, because most people do not actually take part in the practical or physical application of this belief (i.e. the killing of certain animals to obtain ecological stability), they are somewhat sheltered from this uncomfortable realisation. Furthermore, the practical or physical application of these beliefs highlights another important feature for understanding human-nature relationships. Taking on the role of manager (or steward) highlights a certain belief that humans are in charge of the situation. Such a relation contains significant aspects of domination and arrogance because it implies, firstly, that this is something that humans can know and, secondly, that humans can do something about it. This view is rather troubling, particularly when one views the contention within contemporary ecology debates surrounding the concept of the stable ecosystem (Demeritt, 1994; Swyngedouw, 2007; Zimmerer, 1994). As highlighted by Zimmerer (1994), the ecological concept of nature tending towards stability and equilibrium has for some time been questioned through an examination of the "instability, disequilibria, and chaotic fluctuations that characterise many environmental systems" (p. 109). Such an examination casts grave doubts over both the pursuit of ecosystem stabil- ity and the question of whether ecosystem stability (in any form) is actually obtainable (Castree, 2001, 2003; Demeritt, 1994; Swyngedouw, 2007). Leaving aside conjectures about what is known and not known for a moment, such an interaction as described above also highlights an assumption as to the separation of society and nature. However this appears to be an assumption that lacks weight because - while it may be possible to separate society from nature, thanks to the managerial role that is often taken on - it is becoming more and more difficult to separate nature from society. Hunting clearly places considerable pressure on assumptions surrounding society and nature, and also pushes the boundaries, in both a physical and symbolic sense, of the relationship that people have with the natural world. Therefore, the hunters of Switzerland reside in a particularly interesting place. While they may determine their own physical and ethical relationships to the animals they shoot, and the landscape in which this interaction occurs, they are also a key feature within important societal discussions that surround people's moral and physical relationship to the complex and often difficult-to-tie-down thing that is called nature.

So, what then does that case of the Swiss hunter bring to Castree's (2003) claims about an unavoidable postenvironmental ethics? Well, on the surface it seems to strengthen his argument. This case clearly highlights a number of complicated and tangled understandings of and relations to certain aspects of, and indeed the whole of, the natural world. Clearly, any ethical argument or normative prescription about the practice of hunting or, more generally, people's relationship to the natural environment should be sensitive to these wide and varied complexities. Here is the difficulty though. How does one actually do this without becoming hopelessly trapped within ontological debates? Here Proctor (2001) offers an interesting perspective. In opposition to Castree (2003), Proctor (2001) argues that, rather than do away with the universal truth claims deeply embedded within environmental norms, we should closely analyse and examine the numerous and complex social aspects that are contained within any ethical claim. As Proctor (2001) writes:

Let us listen to those who tell us that we must act to save the freshwater species [or whatever we are fighting to protect], ...; they have at some level a legitimate and universally binding claim on reality. And at the same time let us be prepared to challenge the constructedness of their claims, and the constructedness of our own counter-claims, in the spirit of particularistic limitation (p. 236).

This is a quite a practical solution to this ontological dead end. It allows for a step back from the academic field of environmental ethics to view how ethics are social and politically developed and discussed through people's interactions with each other, and the natural world. This perspective takes up the suggestion by Light and de-Schalit (2003) that environmental philosophers "should find a way to become 
more involved in argumentation that takes place in environmental campaigns and is discussed in the broader environmental literature" (p. 1). Implicit in this view is an understanding that claims on truth and the moralities that are attached to these claims are socially negotiated and struggled over. Furthermore, as shown by the case of the Swiss hunter, the experiences and relations that they have with the animals they hunt, and the landscape in which this interaction occurs, is integrated into the perspectives that they bring to this social debate. Therefore the critique that Castree (2003) offers can be turned into a mode of analysis, which is sensitive both to the relationship that people have to the natural world as well as the social context in which this interaction is embedded. The challenge for those interested in environmental ethics will be uncovering and describing the results of these negotiations. As shown by the case of the Swiss hunter, such an analysis can reveal not only the social aspects of environmental norms but also important features of our own humannature relationship.

\section{Conclusions}

Environmental ethics continues to be a relevant and important topic of discussion: relevant not just in the academic world, but also in everyday life. This is because, as people, we are confronted with a multitude of different moral and ethical conundrums every day. For example, a simple visit to a local supermarket gives rise to a large and complex array of ethical questions and choices. By considering and acting upon (or perhaps not) these ethical questions and choices, people are taking part in a society-wide discussion about humanity's physical and ethical relationship to the natural world. This conversation is undoubtedly important, particularly when we consider the complete reliance that we as people have on the natural environment. Importantly then, environmental ethics gives people a voice to express what they see, feel and think about the natural world, and then connect this to moral considerations. Environmental ethics gives us an array of philosophical tools to analyse why people care about some things (and not others), and to see how these concerns can be justified (Proctor, 2001). However, these voices and claims are often confusing, contradictory and even paradoxical: trying to make universal sense of them seems like an impossible challenge (Castree, 2001, 2003). While Castree (2001) highlights the need for "a more supple mode of ethical reasoning" (p. 3), it seems difficult to image how, for example, environmental perspectives such as animal rights/liberation, bio/eco-centrism, the land ethic or deep ecology could possibly account for all these variations and complexities while still retaining a general appeal. That is however the point. Perhaps it is time for those interested in environmental ethics to broaden their horizons and look beyond the construction of environmental norms (in the sense of attempting to create sets of more or less uni- versally applicable guidelines for people to interact with the natural world), toward describing and making sense of the society-wide negotiations that surround the moral relationship that people have with the natural world. A development such as this is clearly an area which human geographers can both contribute to and profit from. Because engaging with the morality and ethics explicitly and implicitly expressed by people as they discuss important environmental questions (such as the ones that surrounds hunting practices) offers human geographers fertile ground on which to interrogate and make sense of the ways that people understand the natural world.

Acknowledgements. I would like to thank all those that helped me put together this research paper - in particular, the participants for their time and interest, the reviewers, Olivier Graefe, Olivier Ejderyan and my colleagues for all their helpful comments and advice.

Edited by: B. Korf

Reviewed by: two anonymous referees

\section{References}

Altherr, T. L. and Reiger, J. F.: Academic historians and hunting: A call for more and better scholarship, Environmental history review, 19, 39-56, 1995.

Amt für Jagd und Fischerei Graubünden,: Jahresbericht Jagd 2013, Retrieved from: http://www.gr.ch/DE/institutionen/verwaltung/ bvfd/ajf/dokumentation/jagd/Seiten/Jahresberichte.aspx, 2013.

Atkinson, R. and Flint, J.: Snowball sampling, in: The sage encyclopaedia of social science research methods volume 3, edited by: Lewis-Beck, M. S., Bryman, A., and Liao, T. F., 1043-1044, Sage Publications Inc: Thousand Oaks, USA, 2004.

Blankenhorn, H.: Jagd: Von 1875 bis heute, Historisches Lexikon der Schweiz, http://www.hls-dhs-dss.ch/textes/d/D13942.php (last access: 24 January 2014), 2008.

Breitenmoser, U.: Large predators in the Alps: The fall and rise of man's competitors, Biol. Conserv., 83, 279-289, 1998.

Bundesamt für Umwelt: Jagdsysteme, retrieved from: http://www. bafu.admin.ch/jagd-fischerei/07833/07883/index.html?lang=de, 2010.

Bundesamt für Umwelt: Eidgenössische Jagdstatistik, http://www. wild.uzh.ch/jagdst/ (last access: 24 January 2014), 2013.

Cahoone, L.: Hunting as a moral good, Environ. Value., 18, 67-89, 2009.

Callicott, J.: In defence of the land ethic, CUNY Press, Albany, N.Y., 1989.

Canton Grisons: Jagd und Fischerei, http://www.gr.ch/DE/kanton/ ueberblick/Seiten/JagdundFischerei.aspx, last access: 24 January 2014.

Cartmill, M.: A view to a death in the morning: Hunting and nature through history, Harvard University Press, USA, 1996.

Carvalhedo Reis, A.: More than the kill: hunter's relationship with landscape and prey, Current issues in tourism, 12, 573-587, 2009. 
Castree, N.: Socializing nature: Theory, practice, and politics, in: Social nature: Theory, practice \& politics, edited by: Castree, N. and Braun, B., 1-21, Blackwell Publishing, Malden, USA, 2001.

Castree, N.: A post-environmental ethics, Ethics, Place and Environment, 6, 3-12, 2003.

Clifford, N. J., French, S., and Valentine, G.: Getting started in geographical research, in: Key methods in geography (2nd edition), edited by: Clifford, N. J., French, S., and Valentine G., 3-15, Sage Publications Ltd., London, 2010.

Demeritt, D.: Ecology, objectivity and critique in writings on nature and human societies, Journal of historical geography, 20, 22-37, 1994.

Dickson, B.: The ethics of recreational hunting, in: Recreational hunting, conservation and rural livelihoods: Science and practice, edited by: Dickson, B., Hutton J., and Adams, W. M., 59-72, Blackwell Publishing Ltd., West Sussex, UK, 2009.

Die Bundesversammlung der Schweizischen Eidgenossenschaft: Bundesgesetz über die Jagd und den Schutz wildlebender Säugetiere und Vögel, http://www.admin.ch/ch/d/sr/c922_0. html, last access: 24 January 2014.

Flick, U.: An Introduction to qualitative research fourth edition, Sage, London, 2009.

Franklin, A.: Nature and social theory, Sage, London, 2002.

Gunn, A. S.: Environmental ethics and trophy hunting, Ethics and the Environment, 6, 68-95, 2001.

Harvey, D.: Justice, nature and the geography of difference, Blackwell publishing, Oxford, 1996.

Imoberdorf, I.: Deutungskampf im Oberwallis: Interessenverbände in der Debatte um den Wolf, Masterarbeit, Geographisches Institute, Universität Zürich, 2012.

Keel, M.: The Killing game: An ecofeminist critique of hunting, J. Philos. Sport, 23, 30-44, 1996.

Knezevic, I.: Hunting and environmentalism - Conflict or misperceptions, Human dimensions of wildlife, 14, 12-20, 2009.

Leader-Williams, N.: Conservation and hunting: Friend or foes, in: Recreational hunting, conservation and rural livelihoods: Science and practice, edited by: Dickson, B., Hutton, J., and Adams, W. M., 9-24, Blackwell Publishing Ltd., West Sussex, UK, 2009.

Lee, K.: Awe and humility, in: Philosophy and the natural environment, edited by: Attfield, R. and Belsey, A., 34-45, Cambridge University Press, Cambridge, 1984.

Lewis, C. S.: Studies in words, Cambridge University press, Cambridge, 1960.

Light, A. and de-Shalit, A.: Introduction: Environmental ethics Whose philosophy - Which practice?, in: Moral and political reasoning in environmental practice, edited by: Light, A. and deShalit, A., 1-27, Massachusetts Institute of Technology, USA, 2003.

Marvin, G.: Sensing nature: Encountering the world of nature, Etnofoor, 18, 15-26, 2005.

Marvin, G.: Challenging animals: Project and process in hunting, in: Nature and culture: Rebuilding lost connections, edited by: Pilgrim, S. and Pretty, J., 145-159, Earthscan Ltd., London, 2010.

McLeod, C. M.: Dreadful/delightful killing: The contested nature of duck hunting, Society and animals, 15, 151-167, 2007.
Müller, K.: Jagd: Die Entwicklung der Jagd bis zum Bundesgesetz von 1875, Historisches Lexikon der Schweiz, http:// www.hls-dhs-dss.ch/textes/d/D13942.php (last access: 24 January 2014), 2008.

Müller, T.: Der Umgang mit geschützten Tieren, insbesondere die Regulierung von Grossraubtieren: Rechtsgutachten in Auftrag von JagdSchweiz, Zusammenfassung, retrieved from: http: //www.jagdschweiz.org/de/grossraubtiere.php, 2008.

Murdocca, M., Jupiter, A., Moore, S., Carls, J. B. (Producers), and Culton, J., Allers, R., Stacchi, A. (Directors): Open season [Motion picture], Sony Picture Animation, USA, 2006.

Naess, A.: Ecology, community and lifestyle, Cambridge University press, Cambridge, 1989.

Ortega y Gasset, J.: Meditations on hunting (second edition), Wilderness Adventure Press Inc., Belgrade, Montana, 1996.

Peterson, M. N., Hanson, H. P., Peterson, M. J., and Peterson, T. R.: How hunting strengthens social awareness of coupled humannature systems, Wild biology in practice, 6, 1-17, 2011.

Pojman, L. P.: On ethics and environmental concerns, in: Environmental ethics: Reading in theory and application, edited by: Pojman, L. P., 1-3, Belmont, CA, Thomson \& Wadsworth, 2005.

Proctor, J. P.: Solid rock and shifting sands: The moral paradox of saving a socially constructed nature, in: Social nature: Theory, practice \& politics, edited by: Castree, N. and Braun, B., 225240, Blackwell Publishing, Malden, USA, 2001.

Rolston III, H.: Environmental ethics, in: The Blackwell companion to philosophy (second edition), edited by: Bunnin, N. and TsuiJames, E. P., 517-530, Blackwell Publishing, Malden, USA, 2003.

Schweizer Fernsehen (Producer): Auf der Jagd (Television series episode), in Einstein, Zurich: Schweizer Fernsehen, http://www.videoportal.sf.tv/video?id= bfda6a2e-1723-4998-a0cd-9a21fa366ac5 (last access: 24 January 2014), 10 October 2008.

Simpson, S. V. and Cain, K. D.: Recreation's role in the environmental ethics dialogue - The case of Aldo Leapold and the morality of hunting, Leisure/Loisir, 25, 181-197, 2001.

Singer, P.: Animal liberation, Routledge, London, 1975.

Swyngedouw, E.: Impossible "sustainability" and the post-political condition, in: The sustainable development paradox: Urban political economy in the United States and Europe, edited by: Gibbs, D. and Krueger, R., 13-40, Guilford Press, New York, 2007.

Valentine, G.: Geography and ethics; Questions of considerability and activism in environmental ethics, Prog. Hum. Geogr., 28, 258-263, 2004.

Wallner, A. and Hunziker, M.: Die Kontroverse um den Wolf - Expertenimterviews zur gesellschaftlichen Akzeptanz des Wolfes in der Schweiz, Forest, snow and landscape research, 76, 191-212, 2001.

Williams, J.: The killing game, in: Women on hunting, edited by: Houston, P., 389-403, Eco Press, Hopewell, N.J., 1995.

Zimmerer, K. S.: Human geography and the "new ecology": The prospect and promise of integration, Ann. Assoc. Am. Geogr., 84, 108-125, 1994. 